his way up to a managership, and finally become a wealthy estanciero on his own account. But the author gives the emphatic warning that "Argentina is not a country suitable for the English of the usual emigrant class."

A relief from the monotonous ranch life was the crossing of the Andes into Chile by way of Mendoza, with excursions of several weeks towards Aconcagua and the glaciers of the headwaters of the Tupungato valley, in company of an enthusiastic exploring engineer, who finds his recreation in the climbing of difficult peaks.

The ninety-one original photographs (two of which are here reproduced by the courtesy of the publishers) are excellent representations of a multitude of scenes from lassoing gauchos, sheep-shearing, and locustplagues, to shifting dunes amongst lagoons, glaciers, and nieves penitentes.

\section{THE ERUPTION OF ETNA.}

I $N$ the last issue of Nature (p. 368), a brief reference was made to what has proved to be a somewhat important eruption of Etna. Our knowledge of the successive phenomena is still scanty, the telegrams inserted in English newspapers being short; but, from the more lengthy accounts given in the Corriere of Catania, some further details may be gleaned.

The eruption was, as usual, preceded by a series of tremors interspersed with stronger shocks. At Mineo, which lies about 35 miles S.S.W. of Etna, the first movement was recorded on September Io, at $0.5^{8}$ a.m., followed for more than fifteen hours by almost incessant tremors. After 4.28 p.m., however, a period of calm ensued, which for at least twentyfour hours was interrupted by only one disturbance; and, even at Linguaglossa (about ten miles north-east of the central crater), the shocks had become so infrequent and so slight that the inhabitants were no longer awakened by them.

Almost concurrently with the first tremors, black clouds of vapour and ashes were seen to rise from Etna. The first new vent was opened at 4.30 a.m. on September Io on the northern flank of the mountain to the north-west of M. Frumento, ${ }^{1}$ and at a height of about 9200 feet; the second, at $9.40 \mathrm{a} . \mathrm{m}$. , in the neighbourhood of $M$. Nero; in both cases an hour or more after pronounced shocks. From both openings there issued dense clouds, with lapilli, sand and ashes, but no lava. Later in the day, at I2. I5, a third vent appeared, near M. Crozza, and a little later a fourth, near Castiglione Sicilia. After this, new vents opened in rapid succession. On September is there were sixteen in action, of which fourteen ejected vapour and dust, and the other two, lower down, lava. On September I3 Prof. Ricco reported that as many as 54 vents had opened in the region between M. Rosso and the craters formed in 1879 . The central crater also ejected an immense quantity of ashes, which have covered the surrounding country to the depth of several inches.

During the first day there seems to have been no outflow of lava. At I.3o a.m. on September II, however, during a period of comparative seismic calm, a new vent opened between $M$. Rosso and M. Nero, at a height of about $5^{2} 50$ feet, with enormous emission of dust, \&c., followed by a stream of lava. Five hours later another vent appeared in the same district, from which a copious stream of lava issued. The streams rapidly descended the steep slope, passed round M. Rosso and then between the lavas of 1646

1 It should be remembered that some of the names given above are duplicated on Mount Etna. The height of the mountain in rgoo was 10, 758 feet.

No. 2 I86, VOL. 87] and 1809 , thus assuring the safety of Linguaglossa. The main stream presented a front from 12 to 15 yards high, and from 500 to 600 yards wide, and advanced rapidly, sometimes at the rate of a quarter of a mile an hour. During the next two or three days, its velocity was reduced. On September I3, it had crossed the carriage road and circum-Etnean railway; the next day it had approached to within two miles of the Alcantara River, which forms the northern boundary of the volcano. On the ${ }_{1} 5^{\text {th }}$ the main stream split into four subsidiary streams, and the violence of the eruption perceptibly abated. At the time of writing (September I8) the lava stream, the flow of which appeared to be checked, had made another onward movement.

C. Davison:

\section{THE CENTENARY CELEBRATION OF THE UNIVERSITY OF CHRISTIANIA.}

THE delegates of the foreign and national universities and of many academies of science met an enthusiastic reception at the centenary festival. The organisation was admirable throughout, and much useful assistance was given by a number of students, who acted as marshals, and by ladies who had been asked by the University authorities to help in the entertainment. The majority of the professors and students spoke English well, so that if any foreign delegate met with a difficulty--which is improbableat least the way was made smooth for all who spoke English.

The Prime Minister, Mr. Konow, and many of the other high officials of the State associated themselves throughout with the University, so that the festival was regarded not merely as academic but also as national.

On the afternoon of Monday, September 4, a short reception was held at the University by the rector, Dr. Brögger, to welcome the delegates, who numbered about I3o, and to explain the expediency of dividing us into twelve groups, according to the geographical positions of our several countries. Each group was requested to choose a spokesman, and I had the honour of being chosen to represent the British Empire.

On the evening of Monday the doctors and professors of the University invited their foreign and Norwegian guests, to the number of three or four hundred, to supper at the Grand Hotel. Before supper Prof. Morgenstjerne gave us a cordial welcome in a speech delivered in French, and afterwards we went to the dining-rooms, of which there were several, and supped in groups of skilfully chosen parties of congenial spirits.

The more formal part of the festival took place the following morning (Tuesday, September 5) at the National Theatre. Dr. Brögger presided on the stage, to which access was given by two gangways on each side of the orchestra. The King and Queen honoured the meeting with their presence; and the spectacle was brilliant with the dresses of the ladies, the academic robes, and bright uniforms.

The proceedings began with a cantata composed by Mr. Winter Hjelm, of which the words are by Björnson, entitled "Lyset" (the Light), sung by the students, both men and women, with a full orchestra. After two parts of the cantata had been given Dr. Brögger addressed the audience in German on the history of the University. The groups of delegates then presented their several addresses of congratulation, and each spokesman delivered a speech of a few minutes in length. The rest of the 